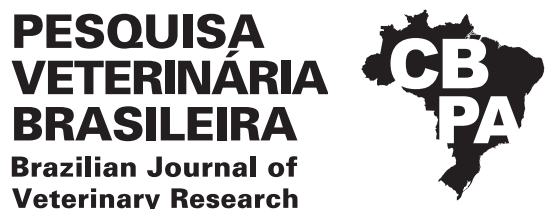

Pesq. Vet. Bras. 40(5):399-407, May 2020 DOI: 10.1590/1678-5150-PVB-6390

Original Article

inarv Research

Small Animal Diseases

ISSN 0100-736X (Print)

ISSN 1678-5150 (Online)

\title{
Seroprevalence and incidence of Leptospira spp. in domestic dogs in the Southeast region of São Paulo State, Brazil ${ }^{1}$
}

\author{
Anaiá P. Sevá ${ }^{2,3 *} \mathbb{D}$, Ana Pérola D. Brandão², Silvia N. Godoy ${ }^{4}$, Gisele O. Souza², \\ Antonio Francisco Souza Filho ${ }^{2}$, Tatiana Jimenez-Villegas ${ }^{2}$, \\ Marcos Bryan Heinemann ${ }^{2}$ and Fernando Ferreira ${ }^{2}$
}

\begin{abstract}
Sevá A.P., Brandão A.P.D., Godoy S.N., Souza G.O., Souza Filho A.F, Jimenez-Villegas T., Heinemann M.B. \& Ferreira F. 2020. Seroprevalence and incidence of Leptospira spp. in domestic dogs in the Southeast region of São Paulo State, Brazil. Pesquisa Veterinária Brasileira 40(5):399-407. Embrapa Suínos e Aves, Rodovia BR-153 Km 110, Cx. Postal 21, Distrito de Tamanduá, Concórdia, SC 89700-000, Brazil. E-mail: anaiaps@usp.br

Leptospirosis is a zoonotic disease caused by Leptospira and domestic dogs can act as host of some serovars. In order to analyze the transmission dynamics in a dog population, with and without immunization, a longitudinal study was carried out with a focus to evaluate antibody response and to identify serovars. Blood samples were collected in three consecutive years (2015 to 2017) from 331, 373 and 347 dogs respectively. The dog seroprevalence in each year was $11 \%, 7 \%$ and $14 \%$, respectively, and the incidence in 2016 was $5 \%$ and in $2017,14 \%$. The most frequent serovars were Cynopteri and Butembo in 2015, Cynopteri, Butembo and Hardjoprajitno in 2016, and Canicola and Butembo in 2017. Dogs can play a role as sentinel animals and hosts of Leptospira serovars. The percentage of seropositive dogs due to vaccination was higher than the previous years without immunization and lower than in previous years for other serovars, which we interpret as evidence for the importance of immunization. These parameters associated with active canine population control are important for prevention and control of leptospirosis not only in dogs but alsoto inhibit the transmission between dogs and humans.
\end{abstract}

INDEX TERMS: Seroprevalence, Leptospira spp., domestic dogs, São Paulo, Brazil, program, immunization, vaccine, dogs, Cãoservação Program.

RESUMO.- [Soroprevalência e incidência de Leptospira spp. em cães domésticos na região sudeste do estado de São Paulo, Brasil.] A leptospirose é uma zoonose causada pelo agente etiológico Leptospira. Cães domésticos atuam como hospedeiro de diversos sorovares deste agente. Com intuito de analisar a dinâmica da leptospirose em uma população canina, com e sem imunização, um estudo longitudinal foi realizado avaliando a resposta sorológica destes animais e identificando seus sorovares. Foram coletadas amostras

\footnotetext{
${ }^{1}$ Received on January 27, 2020.

Accepted for publication on February 17, 2020.

${ }^{2}$ Departamento de Medicina Veterinária Preventiva e Saúde Animal, Universidade de São Paulo (USP), Av. Prof. Orlando Marques de Paiva 87, São Paulo, SP 05508-010, Brazil.

${ }^{3}$ Departamento de Ciências Exatas e Tecnológicas, Universidade Estadual de Santa Cruz (UESC), Campus Soane Nazaré de Andrade, Rod. Jorge Amado Km 16, Salobrinho, Ilhéus, BA 45662-900, Brazil.

${ }^{4}$ Instituto Chico Mendes de Conservação da Biodiversidade (ICMBio), Rod. Dr. Manoel Hipólito do Rêgo 1907, Praia do Arrastão, São Sebastião, SP 11610 000, Brazil. *Corresponding author: anaiaps@usp.br, napaixao@hotmail.com
}

de 331, 373 e 347 cães em três anos consecutivos (2015 a 2017). As soroprevalências foram de $11 \%, 7 \%$ e $14 \%$, respectivamente, e a incidência em 2016 foi de $5 \%$ e em 2017 de $14 \%$. Os sorovares mais frequentes foram Cynopteri e Butembo em 2015, Cynopteri, Butembo e Hardjoprajitno em 2016, e Canicola e Butembo em 2017. Estes cães estão atuando como bio-indicadores da presença de Leptospira na região do estudo, incluindo sorovares zoonóticos, e contribuindo com a sua manutenção no ambiente. A soropositividade para sorovares protegidos pela vacina foi mais alta do que nos anos anteriores à imunização, enquanto para os sorovares não protegidos pela vacina diminuiu, demonstrando a importância da imunização para essa população de cães. Medidas de prevenção e controle para a leptospirose, como imunização e controle populacional canino, são recomendadas no local para inibir a transmissão do agente entre as populações de cães e humanos envolvidas.

TERMOS DE INDEXAÇÃO: Soroprevalência, Leptospira spp., cães domésticos, São Paulo, Brasil, imunização, vacina, caninos, Programa Cãoservação. 


\section{INTRODUCTION}

Leptospirosis is a zoonotic disease caused by the bacteria Leptospira and it affects most mammalian species (Acha \& Szyfres 2001). Human leptospirosis in Brazil is considered a neglected disease and requires mandatory notification (Brasil 2017). Although the number of human cases has declined in recent years (from 4,676 in 2014 to 2,930 in 2017), disease occurrence is still high, being São Paulo State the most affected (18.6\% in 2017) (Brasil 2019).

Domestic dogs contribute to the maintenance of pathogens such as the Leptospira, that can be transmitted to both wild animals and humans (Courtenay et al. 2001, Doherty et al. 2017). Canine leptospirosis can be a serious public health issue, due to the pathogenicity, extended shedding period (Ávila et al. 1998), and the potential contagion established by the proximity between humans and dogs (Brasil 1998, Polachini \& Fujimori 2015).

The course of infection and severity of symptoms vary according to the serovar, host species and host immune status (Maria \& Kimura 2002). Leptospirosis is commonly asymptomatic (Levett 2001) and the clinical manifestations vary from subclinical to lethal (Levett 2001, Polachini \& Fujimori 2015), being the symptoms related to renal insufficiency and vascular disorders (Birnbaum et al. 1996, Levett 2001). The bacteria affects kidneys and is excreted with the urine, remaining at the environment mostly in water sources (Polachini \& Fujimori 2015).

There are 21 reported species of Leptospira and more than 300 identified serovars (Faine et al. 1999). Each serovar has one or more specific host species and one mammalian species can host more than one serovar (Levett 2001). In Brazil, the most important serovar in humans is Icterohaemorrhagiae (Nascimento et al. 2004), which is also important for dogs, in addition to Canicola and Copenhageni (Sakata et al. 1992, Scanziani et al. 1994, Jorge et al. 2017, Pinto et al. 2017).

The occurrence of leptospirosis varies in different geographical areas and is affected by socioeconomic characteristics; climatic conditions, including high temperature, rainfall and by biologic features, such as the presence of wild and domestic reservoirs (Brod et al. 2005). Therefore, if humans and domestic dogs share the same environment, investigation leptospirosis in dogs is of utmost importance for successful prevention and control, including in humans (Brod et al. 2005, Polachini \& Fujimori 2015). It is also important to point the fact that the transmission of the disease by dogs is especially common when they are unvaccinated, a usual situation in rural and low-income areas (Martinez et al. 2013).

This study was performed in a small district, close to a Conservation Unit of São Paulo State, Brazil, and aimed to analyze the dynamics of leptospirosis in a domestic dog population, evaluating their serological response in three consecutive years, being that in the second year, the animals were vaccinated in order to compare seroprevalence before and after immunization.

\section{MATERIALS AND METHODS}

Study area. Two neighborhoods of São Miguel Arcanjo municipality were included in the study, Abaitinga and Gaviões, located in the surrounding of the "Parque Estadual Carlos Botelho" (CBSP), São Paulo State, Brazil. Dogs had access to the street and to the Park and were non-vaccinated. The area is as a rural zone with a subtropical, humid climate (an average annual temperature of $18^{\circ} \mathrm{C}$ and a monthly average rainfall over $40 \mathrm{~mm}$ ) without a dry season and with a hot summer .(Alvares et al. 2013).

Data and biological sample collection. In April of 2015, 2016 and 2017 all residences of the neighborhoods were visited for biological sampling of all domiciled dogs. (1st, 2nd and 3rd collection, respectively). During the visits, the owners signed a "free and informed consent form", which was approved by the Ethics Commission of Animal Use (CEUA) of the "Faculdade de Medicina Veterinária e Zootecnia" of the "Universidade de São Paulo" (FMVZ-USP) under protocol number CEUA 2452231014. After the owner's authorization, the residence was geo-referenced (Fig.1), dogs were identified and their blood samples were collected from the jugular, cephalic or femoral vein. Samples were stored at $5^{\circ} \mathrm{C}$ for a maximum of five hours until serum was extracted by centrifugation at 1500 rpm for 10 minutes. Sera were stored at $-20^{\circ} \mathrm{C}$ for serological analysis at the "Laboratório de Zoonoses Bacterianas" of the FMVZ-USP.

Laboratory analysis. A microscopic agglutination test (MAT) using live antigens Cole et al. 1973 was performed to measure binding antibody levels using cultures of 24 serovars of Leptospira maintained in EMJH (Ellinghausen McCullough Johnson Harris) medium as antigens (Table 1). Sera were diluted 1:50 in Sorensen buffered saline solution. Reactions were performed in polystyrene microplates with $50 \mu \mathrm{l}$ of antigen. All samples with agglutinant activity at a dilution of 1:100 (cutoff point) were considered positive and titrated in two-fold serial dilutions. The highest titer reached with at least $50 \%$ of agglutinated Leptospira was used as cut-off to identify the infective serogroup (Myers 1985).

Immunization. During the 2nd collection, the dogs were immunized with the polyvalent Biovet ${ }^{\circledR}$ vaccine, which contains a lysed concentrate of Leptospira canicola, L. icterohaemorrhagiae, L. grippotyphosa, L. copenhageni and L. pomona. The vaccine was administered according to the manufacturer's recommendations to all clinically healthy dogs over 4 months old.

Data analysis. Most probable serovar: when the animal presented seropositivity for more than one serovar, the serovar with the highest titer and with a dilution twice as high as that of the serovar with the second highest titer was considered. In cases where the animal presented more than one serovar having the highest titer at the same dilution or with a single dilution of difference, the result was considered undetermined, because it was not possible to confirm the causative agent of the infection, and was excluded.

The disease incidence was calculated for the 2 nd and $3 \mathrm{rd}$ blood collections considering the population that remained throughout the currently and previous collection. Animals that were seropositive in two consecutive years but for different most probable serovars in each year were considered new cases. The annual seroprevalence of Leptospira spp. was calculated according to the numbers of seropositives by the total sampled population in each year.

Spatial analysis. To identify clusters of leptospirosis cases in dogs, a local spatio-temporal analysis was performed using the computational program SatScan ${ }^{\circledR}$ version 9.4.2. This estimate was evaluated according to the spatial scanning method developed by Kulldorff \& Nagarwalla (1995), which considers qualitative data such as the geographical location of cases (dogs seropositive for Leptospira spp.) and controls (seronegative dogs) (Kulldorff \& Nagarwalla 1995). For each cluster, we performed a likelihood ratio test comparing the hypothesis that the disease risk is higher within the circle with the hypothesis that the risk is equal for the areas inside and outside the circle, with a significance level of $5 \%$. 
The circle with the maximum likelihood ratio was considered the most likely cluster (Wheeler 2007). All maps were built using the QGIS program, version 2.18.

Statistical analysis. To compare results from groups according to age and sex, chi square test was performed using R software, version 3.5.0, considering significance level of $5 \%$.

\section{RESULTS}

Over three years of the study, 189, 200 and 179 residences were visited. Differences in number of residences taken each year are due to unavailability of dog owners even after up to four attempts. Three owners refused to participate. There were collected blood of 331, 373 and 347 animals in each year, respectively, 166 were present in all years. Seventy-five percent of the residences had an area of less than $300 \mathrm{~m}^{2}$ and were in contact or close to paved streets (termed houses), $20 \%$ were rural properties larger than $300 \mathrm{~m}^{2}$ (termed country houses) and $5 \%$ were small properties located inside an agricultural farm (termed farm houses). At the 2nd and 3rd collections, some animals were not available for recollection, due to death or exit from the area. However, some new dogs were included in the studied population due to birth or entrance to the study area (Fig.2). One hundred sixty-six animals were sampled in all three years.

For the 1st, 2nd and 3rd collections, the seroprevalences were $10.9 \%$ (36/331, 95\% CI 7.5-14.2), 7.2\% (26/363, 95\% CI 4.9-10.4) and $13.8 \%$ (48/347, 95\% CI 10.2-17.5), respectively (Table 2). The incidence in the 2 nd year (2016) was $10.13 \%(23 / 227,95 \%$ CI 6.9-14.9) and in the 3rd year (2017) was 19.9\% (95\% CI 15.4-25.7). In the 2nd year, three animals were seropositive for the same serovar that they were seropositive for in the 1st year (and thus were not considered new cases), and in the 3rd year just one dog was seropositive for the same serovar as in the 2 nd year.

Regarding the sex of the animals (Table 2), it was observed that over the two first years, much more males than females were infected; however, this difference was not statistically significant. Some owners did not collaborate in providing information.

Regarding the age of the animals (Table 2), in all years, the seropositivity was lower in young dogs (less than 1 year old). The seroprevalence was significantly higher for adult dogs (1-9 years old) than for old dogs (over 9 years old) at the 3rd collections.

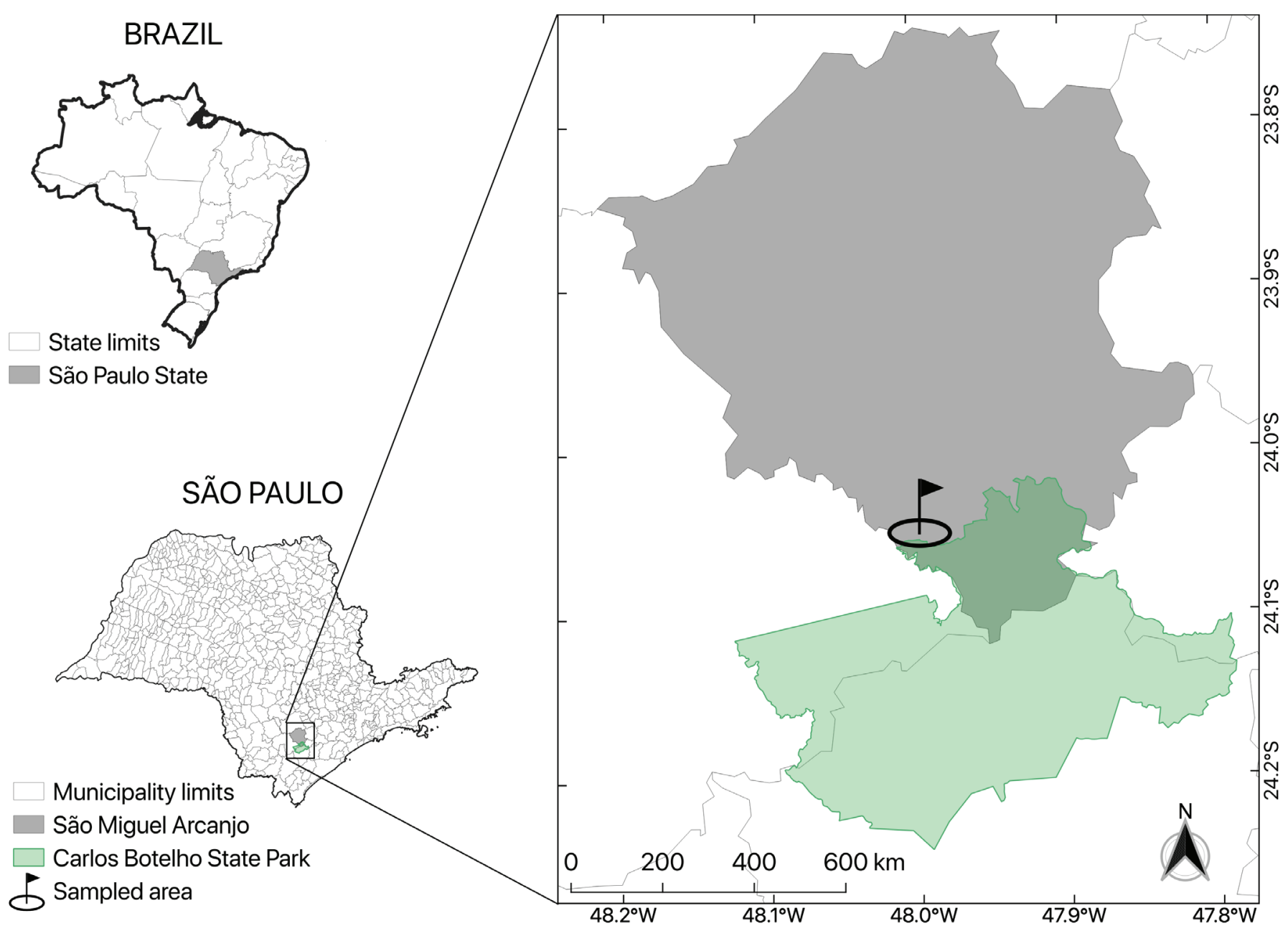

Fig 1. Residences in Abaitinga and Gaviões neighborhoods of São Miguel Arcanjo Municipality with dogs sampled for serological evaluation of Leptospira spp. in three sample collection periods. 
In the 1st collection the most probable serovars were Cynopteri $(71.4 \%, 25 / 35)$ and Butembo $(14.3 \%, 5 / 35)$ and in the 2 nd were Cynopteri $(37.5 \%, 9 / 24)$ followed by Butembo $(16.6 \%, 4 / 24)$ and Hardjoprajitno $(16,6 \%, 4 / 24)$. In the 3rd collection, the most probable serovars were Canicola (53.6\%, $22 / 41)$ and Butembo $(14.6 \%, 6 / 41)$. Some of these positive animals at the 3rd sample collection have been vaccinated at the 2 nd collection (Table 3). Eight seropositive samples were positive for an undetermined serovar.

When the geographic distribution of all seropositive animals for the serovar Canicola was evaluated, it was observed that these animals were not concentrated in a specific region

Table 1. Serovars of live antigen strains of Leptospira used in microscopic agglutination test

\begin{tabular}{cc}
\hline Serogrup & Serologic variant \\
\hline Australis & Australis \\
Australis & Bratislava \\
Sejroe & Guaicura \\
Autumnalis & Autumnalis \\
Autumnalis & Butembo \\
Ballum & Castellonis \\
Batavia & Bataviae \\
Canicola & Canicola \\
Celledoni & Whitcombi \\
Cynopteri & Cynopteri \\
Grippotyphosa & Grippotyphosa \\
Hebdomadis & Hebdomadis \\
Icterohaemorrhagiae & Copenhageni \\
Icterohaemorrhagiae & Icterohaemorrhagiae \\
Javanica & Javanica \\
Panama & Panama \\
Pomona & Pomona \\
Pyrogene & Pyrogenes \\
Sejroe & Hardjoprajitno \\
Shermani & Shermani \\
Tarassovi & Tarassovi \\
Pomona & Pomona \\
Hardjo & Bovis \\
Djasiman & Sentot
\end{tabular}

included in the study (Fig.3). The distributions of the residences with the serological status of the dogs in each year are shown in Fig.4. It is important to highlight that if there was more than one dog at the residence, they overlap in the maps, since each point represents one household. Both seronegative and seropositive dogs are distributed over the whole study area. However, in 2017, a significant cluster was found $(\mathrm{p}=0.030)$ with a prevalence of 75\% (6/8) and relative risk of 7.30 in an area where rural houses are near the CBSP (Fig.4C).

In the present study, few animals had high antibody titers (Fig.5 and 6): one had a high titer for Butembo (800) in the 1st collection; one had a high titer for Grippotyphosa (800) in the 2nd collection; and two had a high titer for Canicola (800 and 3200), one for Hebdomadis (1600), one for Pomona (1600) and one for Guaicura (1600) at the 3rd collection. More dogs presented antibody titer higher than 800 in the 3 rd collection comparing with the other two, although this difference was not statistically significant $(p>0.05)$.

\section{$2015 \quad 2016 \quad 2017$}

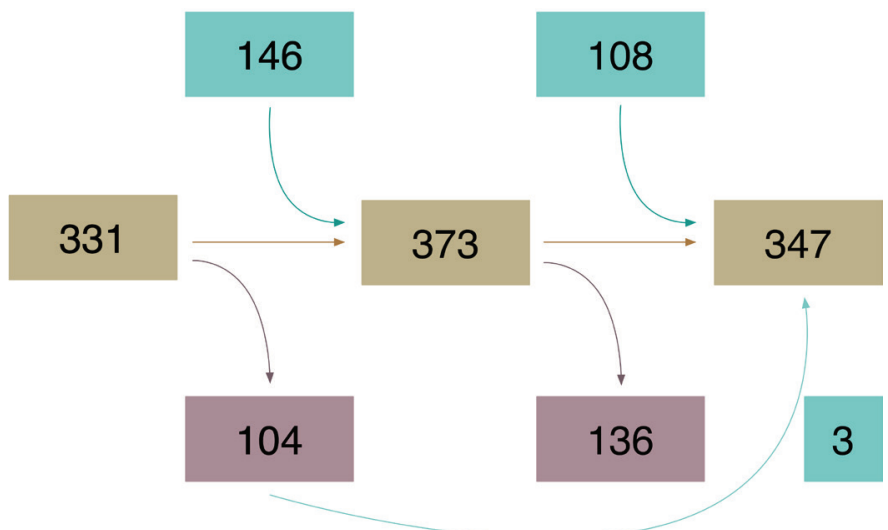

Fig 2. Population dynamic of sampled dogs at the 1st, 2nd and 3rd collection (years 2015, 2016 and 2017, respectively). Sampled dogs in each year (brown boxes), dogs that were not recollected in each year (wine boxes), new dogs included in each year (blue boxes).

Table 2. Seroprevalence of antibodies anti-Leptospira spp. in domestic dogs from the surroundings of Carlos Botelho State Park according to age and gender from 2015 to 2017

\begin{tabular}{|c|c|c|c|c|c|c|c|c|c|c|c|c|c|c|c|}
\hline \multirow{2}{*}{$\begin{array}{c}\text { Age } \\
\text { (years old) }\end{array}$} & \multicolumn{5}{|c|}{2015} & \multicolumn{5}{|c|}{2016} & \multicolumn{5}{|c|}{2017} \\
\hline & Pos & $\%$ & Neg & $\%$ & p-value & Pos & $\%$ & Neg & $\%$ & $\mathrm{p}$-value & Pos & $\%$ & Neg & $\%$ & p-value \\
\hline$<1$ & 2 & $5.6 \%$ & 22 & $7.5 \%$ & 0.399 & 2 & $7.7 \%$ & 35 & $10.4 \%$ & 0.194 & 2 & $4.2 \%$ & 43 & $14.4 \%$ & $0.043^{*}$ \\
\hline $1-4$ & 11 & $30.6 \%$ & 99 & $33.6 \%$ & & 5 & $19.2 \%$ & 101 & $30.0 \%$ & & 14 & $29.2 \%$ & 87 & $29.1 \%$ & \\
\hline$\geq 4-9$ & 11 & $30.6 \%$ & 116 & $39.3 \%$ & & 13 & $50.0 \%$ & 123 & $36.5 \%$ & & 19 & $39.6 \%$ & 106 & $35.4 \%$ & \\
\hline$\geq 9$ & 6 & $16.7 \%$ & 25 & $8.5 \%$ & & 5 & $19.2 \%$ & 30 & $8.9 \%$ & & 7 & $14.6 \%$ & 17 & $5.7 \%$ & \\
\hline WI & 6 & & 33 & & & 1 & & 48 & & & 6 & & 46 & & \\
\hline \multicolumn{16}{|l|}{ Gender } \\
\hline M & 24 & $68.6 \%$ & 154 & $52.9 \%$ & 0.124 & 16 & $61.5 \%$ & 164 & $49.0 \%$ & 0.336 & 23 & $47.9 \%$ & 151 & $51.0 \%$ & 0.844 \\
\hline $\mathrm{F}$ & 11 & $31.4 \%$ & 137 & $47.1 \%$ & & 10 & $38.5 \%$ & 171 & $51.0 \%$ & & 25 & $52.1 \%$ & 145 & $49.0 \%$ & \\
\hline WI & 2 & & 11 & & & 6 & & 9 & & & 0 & & 3 & & \\
\hline
\end{tabular}

Pos = positive, Neg = negative, $\mathrm{WI}=$ without information. 


\section{DISCUSSION}

We found that more males than females were seropositive to Leptospira, however with no statistical significance. Rentko et al. (1992) found this result in dogs, and Andrade (2007) in wild animals which can be explained by the fact that males have the behavior of using larger areas to support reproduction (Andrade 2007).

In our study the seroprevalence was significantly higher for dogs from one to eight years old. Batista et al. (2005) and Sant'Anna et al. (2017) also found higher seroprevalence in dogs over one year old, suggesting that these animals have had more time of exposure to the infectious agent.

In Brazilian studies, it was observed that in Pelotas Municipality (Rio Grande do Sul State), domestic dogs presented a higher level of seropositivity for the Canicola and Icterohaemorrhagiae serovars in the urban zone (Furtado et al. 1997) and for the Icterohaemorrhagiae, Copenhageni, Australis and Canicola serovars in the rural zone (Brod et al. 2005). In Santana do Parnaíba Municipality (São Paulo State), the seroprevalence was $15 \%$, with higher prevalence of Copenhageni, Canicola and Hardjo (Mascolli et al. 2002). In the same State, from 1984 to 1997, in 56.0\% (14/24) of the municipalities studied, the seroprevalence in dogs was $17.9 \%(137 / 795)$, and the most likely serologic variants were Copenhageni and Icterohaemorrhagiae (Favero et al. 2002). In the area of the present study, the seroprevalence was lower than these others and only the serovar Australis was not identified.

Dogs are the main host of serovar Canicola (Rentko et al. 1992), and they can remain reservoirs for a long period of time (Furtado et al. 1997, Miotto et al. 2016). In non-vaccinated dog populations, the incidence of this serovar can reach $50 \%$ or $75 \%$ (Oliveira 2010). In the present study, this serovar was found at a high prevalence only for the 3rd collection (53.7\%), but $91.0 \%$ of the seropositive dogs in that year were vaccinated one year earlier, and this seropositivity rate could be due to the vaccine response. According to Grosenbaugh and Pardo, 65\% $(13 / 20)$ of dogs seroconverted for this serovar post vaccine challenge, however titers declined to undetectable levels in all vaccinates 30 weeks after (Grosenbaugh \& Pardo 2018). However, other authors found titers one year after vaccine challenge (Klaasen et al. 2003). The seropositivity for this serovar, in the present study, represents a low percentage
(8.5\%) of all 234 vaccinated animals that were reevaluated in 2017. It is important to consider that the vaccine is serovarspecific; that is, it only protects against infections caused by the homologous serovar or antigenically similar serovars (Oliveira 2010).

In addition, it could also be possible that serovar Canicola was present in the dog population before our immunization program but was not identified. Miotto et al. (2016) observed that dogs, even seronegative, eliminate the bacteria in the urine (Miotto et al. 2016). Another hypothesis for this increase in the seroprevalence of serovar Canicola is its entrance into this dog population between the 2 nd and 3rd collection. There were only two dogs seropositive for Canicola who were not vaccinated, and these dogs were not present in the studied population before the 3 rd collection. These dogs were adult dogs ( 5 and 15 years old) and lived in the center of the urban area of the municipality. One was a male who had free access to the street and lived in the same residence of another male seropositive for Cynopteri in the previous year. The other one was a female with no access to the street and with no dogs in the same residence.

The fact that the animals seropositive for Canicola were not concentrated in a specific geographic region of the study means that if an outbreak had occurred, it had already spread during the period between the two evaluations ( $2 \mathrm{nd}$ and $3 \mathrm{rd}$ ). The possible spread of the Canicola serovar by the migration of dogs could be explained by the fact that many animals that live in the study area had free access to the street. A condition that can represent a risk factor for Leptospira infection in dogs (Querino Martins et al. 2003).

In the 3rd year, incidence and prevalence of leptospirosis in dogs were higher than those in the 2 nd year. It was observed that among the new cases and vaccinated, 20 were caused by serovar Canicola one by Icterohaemorrhagiae and one by Grippotyphosa. If we exclude these vaccinated and seropositive animals we could consider a lower incidence, and comparing with the previous years could be justified by the effectiveness of the vaccine, however we cannot affirm that because the efficacy for these serovars are not ever observed.

Of all immunized dogs in our study $8.5 \%$ were seropositive for the serovar Canicola. Seroconversion to Leptospira serovar Grippotyphosa, Canicola and Icterohaemorrhagiae followed by vaccination was observed in a total of $50 \%(10 / 20), 65 \%$

Table 3. Seropositive samples for the most probable serovars of Leptospira from 2015 to 2017

\begin{tabular}{|c|c|c|c|c|c|}
\hline Serogroup & Serovars & 2015 & 2016 & 2017 (vaccinated) & Total (\%) \\
\hline Cynopteri & Cynopteri & 25 & 9 & 1 & $34(32)$ \\
\hline Canicola & Canicola & 0 & 0 & $22(20)$ & $22(21)$ \\
\hline Autumnalis & Butembo & 5 & 4 & 5 & $15(14)$ \\
\hline Grippotyphosa & Grippotyphosa & 2 & 1 & $4(1)$ & 7 (7) \\
\hline Sejroe & Guaicura & 2 & 1 & 2 & $4(4)$ \\
\hline Icterohaemorrhagiae & Copenhageni & 0 & 1 & $1(1)$ & $2(2)$ \\
\hline Pyrogene & Pyrogenes & 0 & 1 & 0 & $1(1)$ \\
\hline Ballum & Castellonis & 1 & 0 & 0 & $1(1)$ \\
\hline TOTAL (\%) & & $35(10)$ & $24(6)$ & $41(13)$ & \\
\hline
\end{tabular}


$(13 / 20)$ and $20 \%(4 / 20)$ respectively, and with a decrease after 30 weeks (Grosenbaugh \& Pardo 2018).

The non-vacinated animals presented lower serological titers than the vaccinated animals, which was also found by Wilson et al. (2013). However, serologic data is not sufficient to differentiate vaccine response and infection, since in both cases the serological titers can vary widely, depending on the period after the exposure to the agent or immunization (Ahmad et al. 2005, Grosenbaugh \& Pardo 2018). Thus, in the present study, it is not possible to confirm that the serovar
Canicola was present at the area, different from the serovars Grippotyphosa and Icterohaemorrhagiae, which were detected prior to the vaccination.

On the other hand, if we consider the incidence increase in the $3^{\text {rd }}$ collection as a result of the entrance of the serovar Canicola into the dog population, we could also consider that more frequent vaccination (every six months) could be a preventive measure for dogs and other hosts. Although vaccination doesn't prevent the infection, but rather reduces the
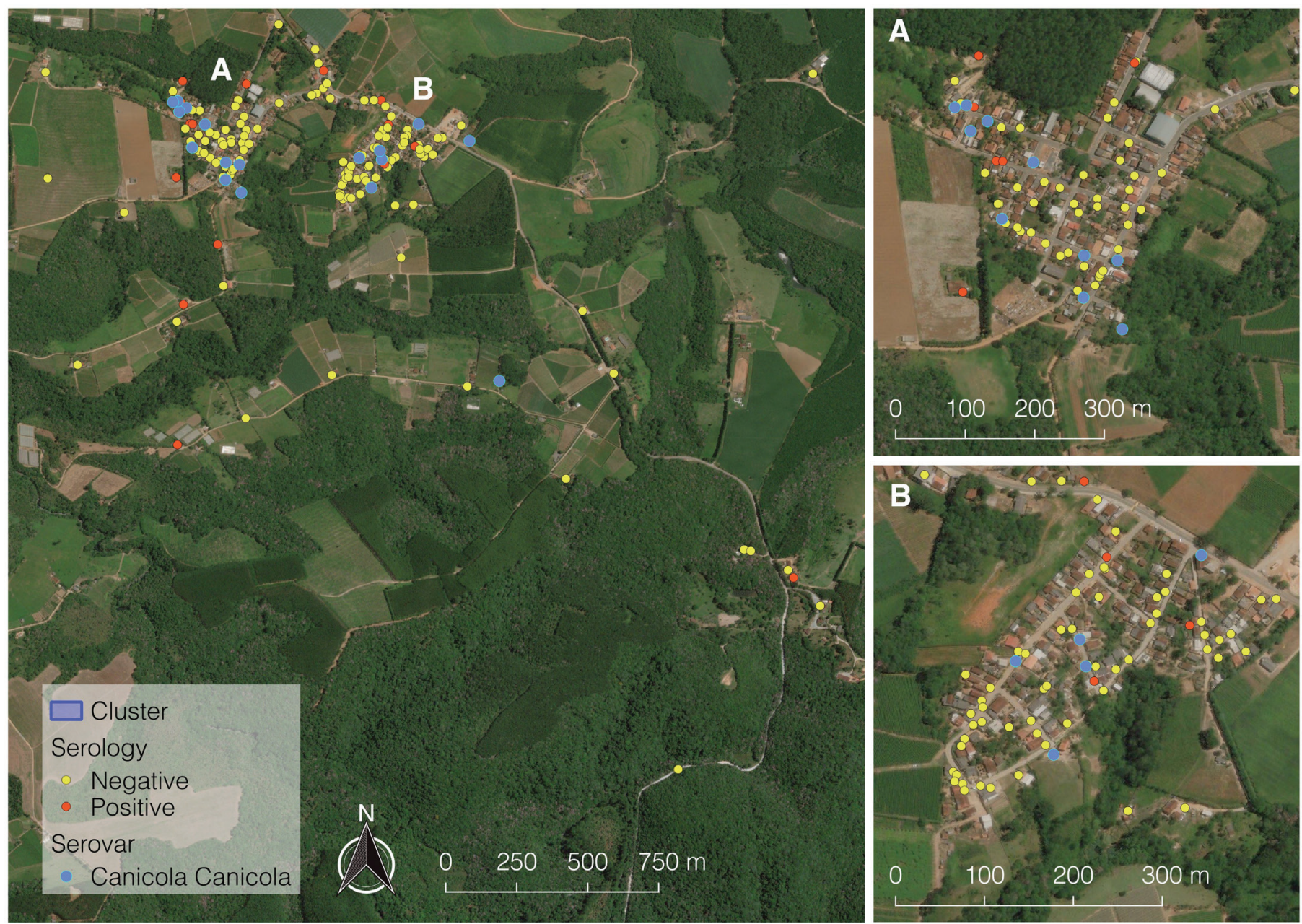

Fig.3. Seronegative and seropositive animals for serovar Canicola in 2017. Abaitinga (A), Gaviões (G). No cluster was found.
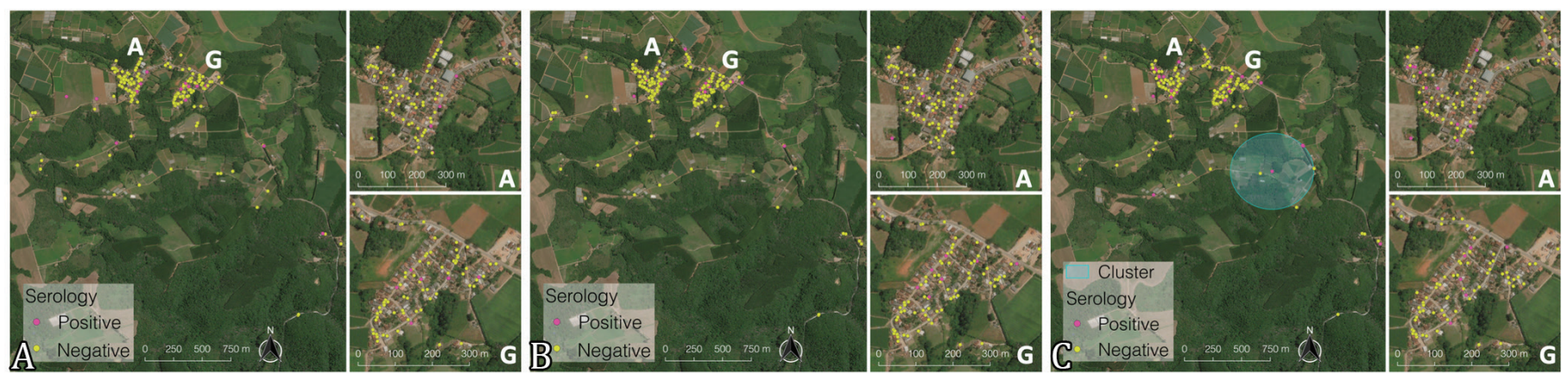

Fig 4. Residences with seronegative dogs and those with dogs seropositive for anti-Leptospira antibody. (A) At the 1st collection (2015),

(B) at the 2nd collection (2016), (C) at the 3rd collection (2017). Abaitinga (A), Gaviões (G). The cluster found has $0.36 \mathrm{~km}$ of radius. 
level of shedding, respectively the likelihood of transmission (Polachini \& Fujimori 2015).

Antibody titers equal to or greater than 800 indicate active infection (Grosenbaugh \& Pardo 2018). In the present study, the majority of animals had a low titer; however, the agent could still be being eliminated in the environment, since dogs with low antibody titers.

The serogroup Icterohaemorrhagiae, which contains Copenhageni serovar, is most important in terms of public health, since it is more frequently related to human infections than other serovars (Nascimento et al. 2004). The sewer rat (Rattus norvegicus) is the most relevant host of the serogroup Icterohaemorrhagiae and is the main reservoir for humans (Nascimento et al. 2004). Although dogs are not considered to be the main reservoirs, they are frequently accidental hosts (Brod et al. 2005). In Brazil serovars in humans cases infected and hospitalized with leptospirosis from 1986 to 1989 in São Paulo State, Brazil, were Copenhageni (77.8\%), and Canicola (11.1\%) (Sakata et al. 1992).

In dogs, most of the studies also found high frequence of Icterohaemorrhagiae and Canicola (Scanziani et al. 1994, Favero et al. 2002, Mascolli et al. 2002, Jorge et al. 2017, Pinto et al. 2017). The present study found few infected dogs by Icterohaemorrhagiae.

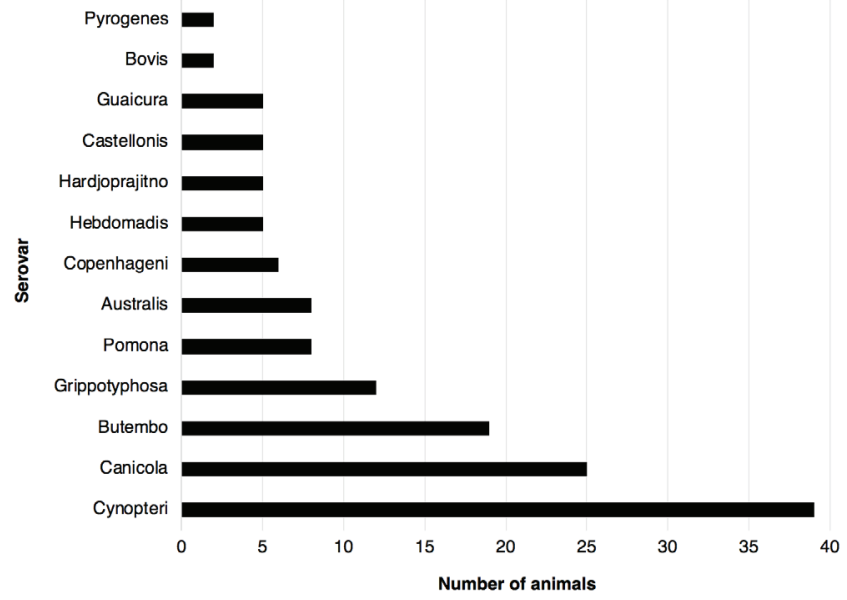

Fig.5. Serovar frequencies for all the three years of study.

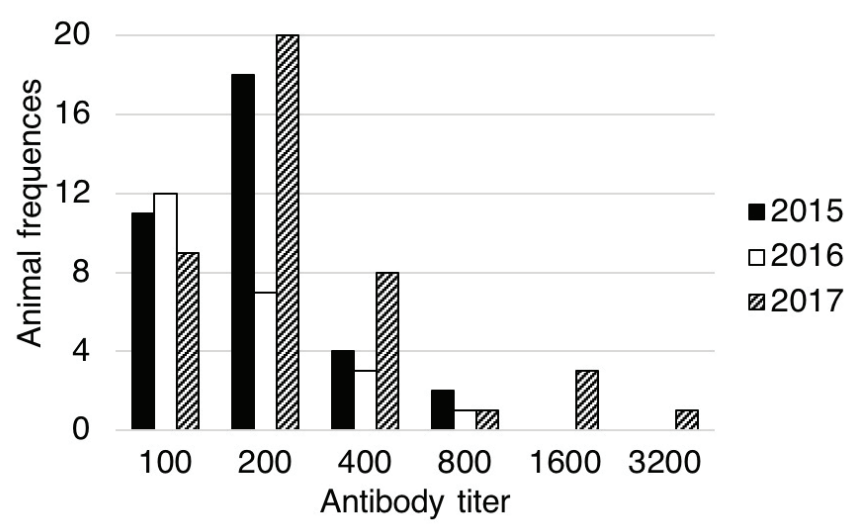

Fig.6. Number of animals and serologic titer variations by year. The median values of titers was 200 in 1st and 3rd collection and 100 at the 2 nd collection.
Nascimento et al. (2004) mentioned that serogroups Pomona and Hardjo have a higher tropism for swine and cattle, respectively (Nascimento et al. 2004). That would not be a problem in the study area, since there were not many dogs seropositive for these serovars and they were geographically distant from the only property with cattle and the only one with swine. The specific Leptospira serovars involved in leptospirosis depend on both the geographic location and the ecology of local hosts (Levett 2001). One route of Leptospira transmission between domestic dogs, wild animals and humans is the contamination of water supplies with infected urine of the hosts. Infected water supplies have already resulted in notable outbreaks of leptospirosis in humans (Levett 2001). The entry of the agent into the host may be through skin lesions, conjunctive membranes or intact skin after prolonged immersion in water (Levett 2001). The contact of dogs with ponds, dams and small pools of water is the main risk factor for canine leptospirosis (Jouglard \& Brod 2000). Thus, the dogs sampled can be considered as bio-indicators of the presence of the serovares in the study area.

Due to the kind of Leptospira transmission by contact, a high density of animals per residences could increases the chance of infection between them. During the year the average ratio of dogs per residence was increasing $1.75,1.86$ and 1.95 such as the incidence. However, only two years is not sufficient to affirm this positive association. There is a high flow of animals at that studied population, with entrance of animals at residences, which can affect in more level the contact between them, than change their density per residences through the period. In addition, the high rate of exit of animals can reduce the contact between them.

The control of Leptospirosis is based on blocking the transmission of the agent (Grosenbaugh \& Pardo 2018). Specific methods can be applied according to the animal population and vaccine availability (Faine et al. 1999, Grosenbaugh \& Pardo 2018). We suggest for the studied area vaccines campaigns for dogs. In addition, there are some domiciled dogs created freely, and, as well as stray dogs, they have access to both street and Park. Hence, they are able to urine in some areas where humans, sometimes barefoot, and wild and other domestic animals also frequent. An indirect way to control leptospirosis is controlling the stray dogs, by sterilization surgery campaigns, and promoting responsible ownership of domiciled dogs.

\section{CONCLUSIONS}

Leptospira spp. are present in the study region, and dogs with high antibody titers were found, mainly in the 3rd collection. The seroprevalence of Leptospira in dogs before and after immunization against Leptospira was evaluated in a naturally exposed population. The high levels of antibodies induced by vaccine can last for months up to a year. The dog seropositivity for serovars protected by vaccine in the 3rd collection, higher than the previous ones, is not necessarily a result of vaccine protection. Therefore, the seropositive dogs found for these serovars can suggest the need of more frequent application intervals of the dog vaccine, as an efficient measure to prevent and control the disease in domestic dogs and consequently in humans and wild animals in the area.

The serovars found in the dogs of this study can also infect humans. So, there is the possibility of a two-way transmission route. Therefore, stimulating the responsible ownership to 
control dog population size, maintain the health of the dogs and vaccinate the dogs against Leptospira can assist in disease prevention in the study area.

The results presented here can contribute to other studies related to the understanding of the leptospirosis dynamic and transmission among different hosts. Analyzing the disease in the dog population, before and after vaccination, consequently helps to plan prevention and control measures to be carried out by public authorities and dog owners.

Aknowledgements.- Funding by grant \#2015/21954-8 and grant \#2015/219666 from "Fundação de Amparo à Pesquisa do Estado de São Paulo" (FAPESP).

Conflict of interest statement.- The authors declare that they have no conflict of interest.

\section{REFERENCES}

Acha P. \& Szyfres B. 2001. Zoonosis y enfermedades transmisibles comunes al hombre y a los animales. Volumen I: bacteriosis y micosis. Org. Panam. Salud 75:263-264. <http://dx.doi.org/10.1590/S1135-57272001000300009>

Ahmad S.N., Shah S. \& Ahmad F.M.H. 2005. Laboratory diagnosis of leptospirosis. Metrop. Heal. 51(3):195-200.<PMid:16333192>

Alvares C.A., Stape J.L., Sentelhas P.C., De Moraes Gonçalves J.L. \& Sparovek G. 2013. Köppen's climate classification map for Brazil. Meteorol. Zeitschrift 22(6):11-728. <http://dx.doi.org/https://doi.org/10.1127/09412948/2013/0507>

Andrade T.M. 2007. Títulos de anticorpos contra Leptospira spp. e análise bioquímica no soro sanguíneo em macaco prego (Cebus apella nigritus). Doctoral Dissertation, Faculdade de Ciências Agrárias e Veterinárias, Universidade Estadual Paulista "Júlio de Mesquita Filho", Câmpus de Jaboticabal, SP. 62p.

Ávila M., Furtado L., Teixeira M., Rosado R., Martins L. \& Brod C. 1998. Aglutininas anti-leptospíricas em cães na área de influência do centro de controle de zoonoses, Pelotas, RS, Brasil, no ano de 1995. Ciência Rural 28(1):107-110. <http://dx.doi.org/10.1590/S0103-84781998000100018>

Batista C.S.A., Alves C.J., Azevedo S.S., Vasconcellos S.A., Morais Z.M., Clementino I.J., Alves F.A.L., Lima F.S. \& Neto J.O.A. 2005. Soroprevalência e fatores de risco para a leptospirose em cães de Campina Grande, Paraíba. Arq. Bras. Med. Vet. Zootec. 57(supl.2):179-185. <http://dx.doi.org/10.1590/ S0102-09352005000800008>

Birnbaum N., Barr S.C., Schermerhorn T. \& Randolph F. 1996. Naturally acquired leptospirosis in 36 dogs: serological and clinicopathological features. J. Small Anim. Pract. 39(5):231-236.<http://dx.doi.org/10.1111/j.1748-5827.1998. tb03640.x><PMid:9631358>

Brasil 1998. Leptospirose Animal. Ministério da Saúde, Brasília DF.

Brasil 2017. Distribuição do número de casos confirmados, coeficiente de incidência, número de óbitos e letalidade, estado de São Paulo, período de 1986 a 2017. Divisão Zoonoses, Sistema de Informação de Agravos de Notificação (SINANW e SINANNET), Centro de Vigilância Epidemiológica (CVE), Centro de Controle de Doenças (CCD), Secretaria do Estado da Saúde de São Paulo (SES-SP), São Paulo, SP. Available at <http://www. saude.sp.gov.br/resources/cve-centro-de-vigilancia-epidemiologica/ areas-de-vigilancia/doencas-de-transmissao-por-vetores-e-zoonoses/ dados/lepto/lepto_ano.pdf> Accessed on Dec. 2019.

Brasil 2019. Leptospirose: casos confirmados notificados no sistema de informação de agravos de notificação. Ministério da Saúde, Brasília, DF.

Brod C.S., Aleixo J.A.G., Jouglard S.D.D., Fernandes C.P.H., Teixeira J.L.R. \& Dellagostin O.A. 2005. Evidence of dog as a reservoir for human leptospirosis: a serovar isolation, molecular characterization and its use in a serological survey. Revta Soc. Bras. Med. Trop. 38(4):294-300. <http://dx.doi.org/10.1590/s0037-86822005000400003><PMid:16082474>
Cole J.R., Sulzer C.R. \& Pursell A.R. 1973. New microtechnique for the leptospiral microscopic agglutination test. Appl.Microbiol. 25(6):976-980. $<$ PMid:4736794>

Courtenay O., Quinnell R.J. \& Chalmers W.S.K. 2001. Contact rates between wild and domestic canids-no evidence of parvovirus or canine distemper virus in crab-eating foxes. Vet. Microbiol. 81(1):9-19. <http://dx.doi. org/10.1016/S0378-1135(01)00326-1><PMid:11356314>

Doherty T.S., Dickman C.R., Glen A.S., Newsome T.M., Nimmo D.G., Ritchie E.G., Vanak A.T. \& Wirsing A.J. 2017. The global impacts of domestic dogs on threatened vertebrates. Biol. Conserv. 210:56-59. <http://dx.doi. org/10.1016/j.biocon.2017.04.007>

Faine S., Adler B., Bolin C. \& Perolat P. 1999. Leptospira and Leptospirosis. 2nd ed. Monash University Print Services, Melbourne. 295p.

Favero A.C.M., Pinheiro S.R., Vasconcelos S.A., Morais Z.M., Ferreira F. \& Ferreira Neto J.S. 2002. Sorovares de Leptospiras predominantes em exames sorológicos de bubalinos, caprinos, equinos, suínos e cães de diversos estados brasileiros. Ciência Rural 32(4):613-619. <http://dx.doi.org/10.1590/S0103-84782002000400011>

Furtado L.R.I., Ávila M.O., Fehlberg M.F.B., Teixeira M.M., Rosado R.L.I. \& Martins L.F.S. 1997. Prevalência e avaliação de fatores de risco à leptospirose canina no Município de Pelotas-RS. Arqs Inst. Biológico, São Paulo, 64:57-61.

Grosenbaugh D.A. \& Pardo M.C. 2018. Fifteen-month duration of immunity for the serovar Grippotyphosa fraction of a tetravalent canine leptospirosis vaccine. Vet. Rec. 182(23):665. <http://dx.doi.org/10.1136/vr.104694> <PMid:29459489>

Jorge S., Schuch R.A., de Oliveira N.R., da Cunha C.E.P., Gomes C.K., Oliveira T.L., Rizzi C., Qadan A.F., Pacce V.D., Coelho Recuero A.L., Soares Brod C. \& Dellagostin 0.A. 2017. Human and animal leptospirosis in Southern Brazil: a five-year retrospective study. Travel Med. Infect. Dis. 18:46-52. <http://dx.doi.org/10.1016/j.tmaid.2017.07.010><PMid:28743546>

Jouglard S.D.D. \& Brod C.S. 2000. Leptospirose em cães: prevalência e fatores de risco no meio rural do município de Pelotas, RS. Arqs Inst. Biológico, São Paulo, 67(2):181-185.

Klaasen H.L.B.M., Molkoenboer M.J.C.H., Vrijenhoek M.P. \& Kaashoek M.J. 2003. Duration of immunity in dogs vaccinated against leptospirosis with a bivalent inactivated vaccine. Vet. Microbiol. 95(1/2):121-132. <http:// dx.doi.org/10.1016/s0378-1135(03)00152-4> <PMid:12860082>

Kulldorff M. \& Nagarwalla N. 1995. Spatial disease clusters: Ddetection and Iinference. Stat. Med. 14(8):799-810. <http://dx.doi.org/10.1002/ sim.4780140809><PMid:7644860>

Levett P.N. 2001. Leptospirosis. Clin. Microbiol. 14(2):296-326. <http://dx.doi.org/10.1128/CMR.14.2.296-326.2001><PMid:11292640>

Maria L. \& Kimura S. 2002. Principais zoonoses, p.201-210. In: Andrade A., Pinto S. \& Oliveira R. (Eds), Animais de Laboratório: criação e experimentação. Editora Fiocruz, Rio de Janeiro. 388p.

Martinez E., Cesario C., Silva I.D.E. \& Boere V. 2013. Domestic dogs in rural area of fragmented Atlantic Forest: potential threats to wild animals. Ciência Rural 43(11):1998-2003. <http://dx.doi.org/10.1590/S010384782013001100013>

Mascolli R., Pinheiro S.R., Vasconcellos S.A., Ferreira F., Morais Z.M., Pinto C.O., Sucupira M.C.A., Dias R.A., Miraglia F., Cortez A., Costa S.S., Tabata R. \& Marcondes A.G. 2002. Inquérito sorológico para leptospirose em cães do município de santana de parnaíba, são paulo, utilizando a campanha de vacinação anti-rábica do ano de 1999. Arqs Inst. Biológico, São Paulo, 69(2):25-32.

Miotto B.A., Moreno L.Z., Guilloux A.G.A., Sousa G.O., Loureiro A.P., Moreno A.M., Lilenbaum W., Vasconcellos S.A., Heinemann M.B. \& Hagiwara M.K. 2016. Molecular and serological characterization of the first Leptospira santarosai strain isolated from a dog. Acta Trop. 162:1-4. <http://dx.doi. org/10.1016/j.actatropica.2016.06.007><PMid:27282095> 
Myers D. 1985. Manual de Métodos, para el Diagnóstico de Laboratório de la Leptospirosis. Centro Panamericano de Zoonosis, s.l. 46p.

Nascimento A.L.T.O., Verjovski-Almeida S., Sluys M.A., Monteiro-Vitorello C.B., Camargo L.E.A., Digiampietri L.A., Harstkeeri R.A., Ho P.L., Marques M.V., Oliveira M.C., Setubal J.C., Haake D.A. \& Martins E.A.L. 2004. Genome features of Leptospira interrogans serovar Copenhageni. Braz J Med Biol Res. 37(4):459-478. <http://dx.doi.org/10.1590/S0100-879X2004000400003>

Oliveira S.T. 2010. Leptospirose canina: dados clínicos, laboratoriais e terapêuticos em cães naturalmente infectados. Doctoral Dissertation, Universidade Federal do Rio Grande do Sul, Porto Alegre, RS. 89p.

Pinto P.S., Libonati H. \& Lilenbaum W. 2017. A systematic review of leptospirosis on dogs, pigs, and horses in Latin America. Trop. Anim. Health Prod. 49(2):231-238. <http://dx.doi.org/10.1007/s11250-016-1201-8> $<$ PMid:27909915>

Polachini C.0. \& Fujimori K. 2015. Leptospirose canina e humana, uma possível transmissão conjuntival no Município de São Paulo, Estado de São Paulo, Brasil. Revta Pan-Amaz. Saúde 6(3):59-65. <http://dx.doi.org/10.5123/ S2176-62232015000300008>

Querino A.M.V., Delbem A.C.B., Oliveira R.C. de, Silva F.G. da, Müller E.E., Freire R.L. \& Freitas J.C. de. 2003. Fatores de risco associados à leptospirose em cães do município de Londrina-PR. Semina, Ciências Agrárias 24(1):27-34. <http://dx.doi.org/10.5433/1679-0359.2003v24n1p27>

Rentko V.T., Clark N., Ross L.A. \& Schelling S.H. 1992. Canine leptospirosis a retrospective study of 17 cases. J. Vet. Intern. Med. 6(4):235-244. <http://dx.doi.org/10.1111/j.1939-1676.1992.tb00345.x><PMid:1522555>

Sakata E.E., Yasuda P.H., Romero E.C., Silva M.V. \& Lombar A.V. 1992. Sorovares de Leptospira interrogans isolados de casos de leptospirose humana em São Paulo, Brasil. Revta Inst. Med. Trop. 34(3):217-221. <http://dx.doi.org/10.1590/S0036-46651992000300006>

Sant'Anna R., Vieira A.S., Grapiglia J. \& Lilenbaum W. 2017. High number of asymptomatic dogs as leptospiral carriers in an endemic area indicates a serious public health concern. Epidemiol. Infect. 145(9):1852-1854. <http://dx.doi.org/10.1017/S0950268817000632><PMid:28367783>

Scanziani E., Calcaterra S., Tagliabue S., Luini M., Giusti A.M. \& Tomba M. 1994. Serological findings in cases of acute leptospirosis in the dog.J.Small Anim. Pract. 35(5):257-260. <http://dx.doi.org/10.1111/j.1748-5827.1994.tb03275.x>

Wilson S., Stirling C., Thomas A., King V., Plevová E., Chromá L., Siedek E., Illambas J., Salt J. \& Sture G. 2013. Duration of immunity of a multivalent (DHPPi/L4R) canine vaccine against four Leptospira serovars. Vaccine 31(31):3126-3130. <http://dx.doi.org/10.1016/j.vaccine.2013.05.043> $<$ PMid:23707443> 